Јасна Бркић

brkicjasna011@gmail.com

Виолета Ђорђевић

violeta_djordjevic@yahoo.com
Стручни рад

UDK 027.022-053.5

028-053.5:[316.774:004

https://doi.org/10.18485/bibliotekar.2019.61.1.6

Библиотека града Београда

\title{
БЕЗ АЛАТА НЕМА НИ ЗАНАТА: СТРУЧНО УСАВРШАВАҢЕ БИБЛИОТЕКАРА ЗА ПРИМЕНУ ДИГИТАЛНИХ АЛАТА У РАДУ СА ДЕЦОМ И МЛАДИМА
}

Сажетак: У уводном делу рада приказане су предности и позитивни ефекти имплементације дигиталних технологија у раду са децом и младима у библиотеци, а у циљу развијања читалачких навика и креативности од најранијег узраста. Услед дигиталне револуције, библиотекарска професија стављена је пред нове изазове. Показало се неопходним систематско развијање позитивног односа библиотекара према новим технологијама, оснаживање информатичких компетенција, континуирано едуковање и охрабривање за коришћење дигиталних алата у раду са децом и младима. Међутим, анализе акредитованих програма за стално стручно усваршавање у библиотечко-информационој делатности, одобрене од стране Народне библиотеке Србије у периоду од 2014. године до 2017. године, показују да изостају програми усавршавања усмерени на подстицање читања код деце уз помоћ примене нових технологија. У раду је, надаље, детаљно представљен семинар Библиотеке града Београда, реализован током 2018. године, „Алатке у руке: креирање и анимација прича уз помоћ ИКТ мајстор(иј)а" у којем је сажето знање и богато искуство управо на пољу примене нових технологија у раду са децом и младима при библиотекама. На крају се приказују сумирани и анализирани резултати евалуације семинара која је спроведена међу полазницима путем анонимног упитника. Заинтересованост великог броја библиотекара за семинар који се бави новим технологијама, те исказана жеља и спремност да савладају дигиталне алате како би их на иновативан начин користили у раду, указују на потребу организовања већег броја семинара који се баве уопште радом са децом, али и инкорпорацијом нових технологија у раду при дечјим библиотекама.

Кључне речи: подстицање читања, дигитални алати, нове технологије, читалачке навике, стручно усавршавање библиотекара, акредитовани семинар, библиотеке за децу. 


\section{Увод}

Систематичан развој културе читања немогућ је без темељног развоја читалачке културе код деце. Но, како су нове технологије овладале готово свим пољима живота, посебна вештина постало је научити децу да читају књиге, фокусирају пажњу и у читању уживају. Телевизија, мобилни телефони, компјутери део су дечје свакодневице безмало од рођења, па је у оваквим околностима увођење деце у свет писане речи све тежи задатак. Статистика је поражавајућа и у свету и код нас, а у брошури Читиаюе са geцом ${ }^{1}$ аналитички се указује на важност развијања читалачких навика од најранијег узраста. Међутим, упркос вишеструкој добробити који читалачке навике доносе, услед дигиталне револуције и лакоће с којом медији успевају да се изборе за дечју пажњу, нове технологије неретко односе превагу над књигом.

Библиотекарска професија такође је стављена пред нове изазове. Библиотекари који раде са децом подстакнути су на константно трагање за решењима како да књигу одрже у центру пажње, а дигиталне алате искористе као моћне савезнике на све комплекснијем путу увођења деце у свет писане речи. Пракса показује да библиотеке, како у свету, тако и код нас, препознају свој потенцијал и значајну улогу у неформалном образовном процесу, те активно стварају стимулативно окружење за учење, унапређују своје услуге и прилагођавају се потребама савременог друштва. Библиотекари који раде са децом и младима све више увиђају неопходност познавања и зналачког коришћења бројних едукативних, креативних и забавних дигиталних алата и апликација који могу имати позитиван ефекат на дечји развој.

\section{ИКТ алати као савезник у пружању подршке читању}

Свакодневно искуство, али и истраживања, како страна тако и домаћа, о коришћењу дигиталне технологије и интернета од стране деце и младих, показују да деца почињу да користе дигиталне уређаје и интернет у све млађем узрасту. Тврдњу поткрепљују и резултати истраживања

UNICEF, Čitanje sa decom, https://www.unicef.org/serbia/sites/unicef.org.serbia/files/2018-07/ Citanje-sa-decom.pdf, (преузето 25.03.2019). 
представљеног у оквиру публикације Деца у gиіитиалном gобу: воgич за

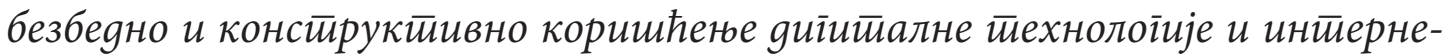
$\bar{u} a .^{2}$ Истраживање је спроведено у Србији средином 2018. године, a peaлизовано од стране УНИЦЕФ-а и Института за психологију. Уочено је да мање од 10\% деце узраста од 4 до 8 година не користи дигиталне уређаје. Седмогодишњаци и осмогодишњаци у великом проценту почињу да користе интернет са пет година, док трогодишњаци и четворогодишњаци откривају свет интернета пре своје треће године. Најчешће активности деце на интернету подразумевају гледање видео-клипова (нпр. You Tube), фотографија, слушање музике, фотографисање и снимање уз помоћ дигиталних уређаја, и играње видео-игара (у предшколском узрасту око 50\% деце, а у млађем школском узрасту преко 80\% деце).

Добијени подаци недвосмислено сугеришу да су медији постали неизоставни део дечјег живота и да их деца користе првенствено у сврху разоноде. Поједини стручњаци оправдано упућују на неопходност употребе компјутера у едукативне и креативне сврхе већ у раду са децом предшколског узраста. Правилно употребљене нове технологије постају „везивно ткиво између деце, васпитача, учитеља, родитеља, а знања и вештине које деца усвајају кроз интеракцију и различите активности само су једна од компоненти васпитно-образовног процеса". ${ }^{3}$ Како деца стичу све више знања пре поласка у школу, нужно је модернизовати процес предшколског васпитања и образовања како би се остварила узајамна повезаност између онога што дете види, чује, схвата и памти, како би што лакше усвајало излагану материју. ${ }^{4}$ Међутим, у истраживању „Ефекти коришћења медија у раном узрасту” као једна од битних препрека интеграције медија у рад са децом предшколског узраста истиче се појава „хроничне забринутости педагошких радника” која резултира посматрањем медија кроз дихотомну слику: добри и лоши медији. Појава најмање сумње у позитивно дејство

2 Публикација је штампана 2019. године и настала је у оквиру пројекта „Безбедан интернет за целу породицу" који су покренули УНИЦЕФ и Теленор, а спроводе Министарство просвете, науке и технолошког развоја и Ужички центар за права детета, https://www.unicef. org/serbia/media/10366/file/Deca_u_digitalnom_dobu.pdf, 14, (преузето 19. 5. 2019).

3 Nataša Anđelković, Dete i računar u porodici i dečijem vrtiću (Beograd: Beoknjiga; Novi Sad: Centar za razvoj i primenu nauke, tehnologije i informatike, 2008), 71.

4 Sonja Veličković, „Edukacija vaspitača za primenu IKT u vrtiću”, Sinteza, Međunarodna naučna konferencija Univerziteta Singidunum (2014), 376, http://portal.sinteza.singidunum.ac.rs/Media/ files/2014/375-378.pdf, (preuzeto 28. 3. 2019). 
нових технологија доводи до избегавања употребе, уместо до покушаја да се о њима дозна више. ${ }^{5}$

Ако се крене од претпоставке да је данашњим „дигиталним" генерацијама књига у папирној форми недовољно стимулативан медиј, за библиотекаре је нужно склапање савезништва са информационо-комуникационим технологијама (у даљем тексту ИКТ) и проналажење иновативних метода рада приликом увођења деце у свет читања. У том смислу неопходно је систематско развијање позитивног односа библиотекара према новим технологијама, оснаживање њихових информатичких компетенција, едуковање и охрабривање за коришћење дигиталних алата у раду са децом и младима. На тај начин, са извесним успехом, може се активно радити на подстицању читања и учења.

Библиотекари Дечјег одељења Библиотеке града Београда, ослањајући се на дугогодишње искуство у раду са децом и младима, а у складу сa IFLA смерницама за библиотечке услуге за децу ${ }^{6}$, настоје да на иновативан и оригиналан начин допринесу популарисању читања, анимирању потенцијалних корисника и потицању деце да користе садржаје културе и буду њихови ствараоци. Кроз радионичарски рад на сигуран начин утиру пут књизи и развијају љубав према читању, а у складу са потребама „дигиталних" генерација, примењују ИКТ алате који се намећу као логичан и промишљен избор и неопходан савезник у пружању подршке читању.

\section{Стручно усавршавање библиотекара}

Познавање медија који су носиоци културног, образовног и информационог садржаја, информационо-комуникационих алата и њихово повезивање са садржајима књижне и некњижне библиотечке грађе посао је који захтева, пре свега, континуирано усавршавање библиотекара. За библиотекаре који имају довољно енергије, воље и времена могућности су бројне, пре свега када је реч о самоиницијативном, необавезном и неформалном образовању. Посредством интернета могућ је увид у бројне примере добре

5 Nataša Starčević, „Efekti korišćenja medija u ranom uzrastu”, Digitalne medijske tehnologije $i$ društveno-obrazovne promene 4 (Novi Sad: Filozofski fakultet, Odsek za medijske studije, 2014), 307, http://odsek.medijskestudije.org/wp-content/uploads/2011/03/Zbornik-Digitalnetehnologije-FINAL.pdf\#page=301 (preuzeto 28. 3. 2019).

6 Ифла Секција за децу и младе, Смернице за библиотечке услуіе за geuy, https://www.nb.rs/ view_file.php?file_id=1831, (преузето 22.3. 2019). 
праксе библиотека широм света, повезивање и дељење искуства, праћење резултата најновијих истраживања у библиотекарству и сродним струкама, приступ електронским часописима, праћење бесплатних стручних скупова и вебинара. Но, када је реч о формалним путевима усавршавања, треба истаћи да је стручно усавршавање библиотекара и књижничара у Србији први пут законски регулисано Законом о библиотечеко-информа-

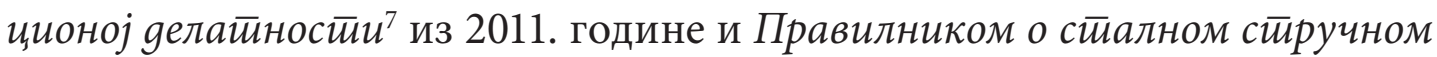
усавршаваюу у библиоиечко-информационој gелайностии ${ }^{8}$ из 2013. године и подразумева шест сати обавезног усавршавања у току године. Народна библиотека Србије је, у складу са наведеним законским одредбама, први пут акредитовала програме стручног усавршавања библиотекара у 2014. години. Од ступања на снагу Правилника до данас, акредитовано је и реализовано шест циклуса програма сталног стручног усавршавања у библиотечко-информационој делатности и то: програми за 2014, 2015, 2016, $2017,2018$. и 2019. годину. Анализом одобрених акредитованих програма у периоду од 2014-2019. године може се закључити да су од 112 одобрених програма само четири усмерена на рад са децом и младима при библиотеци и то: 2014. године „Откриће тајни библиотеке. Увод деце и омладине у коришћење библиотеке и основни видови сусретања са књигом" Ирене Богнар; 2014. и 2015. године „Подстицање читања код деце и младих” Љиљане Косијер и Даниеле Скоковић, 2016. године „Развијање информационе и медијске писмености" Гордане Љубановић и Слађане Галушке и 2018. године „Алатке у руке: креирање и анимација прича уз помоћ ИКТ мајстор(иј)а" Виолете Ђорђевић и Јасне Бркић9.

\section{Програм стручног усавршавања „Алатке у руке: креирање и анимација прича уз помоћ ИКТ мајстор(иј)а"}

О активностима које библиотекари реализују у Дечјем одељењу Библиотеке града Београда и начину имплементације ИКТ алата стручна јавност могла се упознати кроз радове из области библиотекарства и информационих наука објављене у домаћој и страној стручној периодици, као

Службени іласник РС бр. 52 (2011).

Службени іласник РС бр. 18 (2013).

9 Народна библиотека Србије, Стално стручно усавршавање запослених, Одлука о акредитацији програма сталног стручног усавршавања у библиотечко-информационој делатности, https://www.nb.rs/pages/article.php?id=24402 (преузето 25. 3. 2019). 
и кроз бројна излагања на конференцијама. Део активности приказан је, између осталог, на Међународној конференцији „Услуга по мери корисника 21. века: примена информационо-комуникационих технологија у библиотекама" одржаној у Библиотеци града Београда 10-11. децембра 2015. године ${ }^{10}$, на Међународној конференцији „Нове технологије у образовању” у организацији British Council-a, Београд, 9-11. фебруар, 2017. године ${ }^{11}$, као и на Стручно-научном скупу Заједница матичних библиотека Србије БИБЛИОНЕТ 2017 „Информационо-комуникационе технологије и иновативни сервиси у библиотекама", одржаном у Библиотеци града Београда 14-16. септембра 2017. године ${ }^{12}$. Након излагања, бројне колеге показале су заинтересованост за обуку у примени предочених метода и алата.

Мотивисане исказаним интересовањем колега, а имајући на уму новонастале потребе библиотекара за рад са децом, Виолета Ђорђевић и Јасна Бркић, виши библиотекари Дечјег одељења Библиотеке града Београда, понудиле су програм сталног стручног усавршавања у библиотечко-информационој делатности за 2018. годину. Програм се односио на начине стимулисања читања код деце и младих и иновативне приступе у представљању садржаја културе уз помоћ нових технологија. Под називом „Алатке у руке: креирање и анимација прича уз помоћ ИКТ мајстор(иј)а” одобрен је одлуком о акредитацији од стране комисије Народне библиотеке Србије. Реализован је у периоду од фебруара до децембра 2018. године, а похађали су га у највећем броју библиотекари јавних и школских библиотека, али и библиотекари специјалних и високошколских библиотека заинтересовани за коришћење нових апликација и технологија.

Акредитовани семинар „Алатке у руке - креирање и анимација прича уз помоћ ИКТ мајстор(иј)а" реализован је:

- У оквиру новосадског Салона књига и пратеће манифестације Дани библиотека и библиотиекара, 9. марта 2018. године (240 полазника).

- У Електронској читаоници Дечјег одељења „Драган Лукић”, 27. марта (20 полазника), 12. априла (17 полазника), 22. маја 2018. године (13 полазника).

10 Део активности обухваћених програмом стручног усавршавања представљен је у излагању „Ажурирање библиотечких услуга за децу и младе: примена информационих технологија и елемената гејмификације у образовне и креативне сврхе".

11 Део активности обухваћених програмом стручног усавршавања представљен је у излагању,,Storytelling за децу 21. века”.

12 Део активности обухваћених програмом стручног усавршавања представљен је у излагању „ИКТ као моћан савезник библиотекара на путу увођења деце у свет читања”. 
- У организацији Народне библиотеке „Радоје Домановић” Лесковац у Рачунарској учионици Центра за стручно усавршавање у образовању Лесковац, 2. октобра 2018. године (17 полазника).

- Градска библиотека „Владислав Петковић Дис”, Чачак, 2. новембра 2018. године (17 полазника).

- Народна библиотека Ужице, 26. децембра 2018. године (20 полазника).

\section{Предмети, йема и ииль ситручної семинара}

Предмет и тема семинара били су модели употребе информационих технологија у радионицама и програмима за децу и младе при библиотеци; подстицање читања и учења код деце и младих; радионице приповедања прича применом storytelling технике и ИКТ алата; употреба лако доступних компјутерских софтвера и дигиталних алата у библиотеци у образовне и креативне сврхе; оснаживање информатичке писмености библиотекара и корисника библиотечких услуга.

Семинар се састојао из два дела: теоријског и практичног. У теоријском делу представљене су програмске активности и примери добре праксе употребе нових технологија у радионичарском раду са децом и младима при Дечјем одељењу Библиотеке града Београда са сврхом подстицања читања и промовисања услуга библиотеке; детаљно су представљене радионице приповедања прича применом storytelling технике и ИКТ алата; учесници су упознати са апликацијом за прављење и илустрацију прича Kibunet; представљен је програм Comic Life за прављење стрипова и његова употреба за креирање оригиналних прича и препорука књига у форми стрипа, као и могућности програма Inklewriter у радионицама креативног писања.

У практичном делу семинара учесници су упознати са креирањем интерактивних прича са више токова у лако доступном компјутерском софтверу PowerPoint уз помоћ алатке хиперлинк, окушали су се у анимирању ликова и сцена из прича уметањем GIF анимација, као и у илустровању и креирању прича и стрипова уметањем ликова и сцена из компјутерских игара; савладали су израду фото-прича у компјутерском програму Windows Movie Maker, анимирали цртане ликове помоћу интерактивне апликације проширене стварности Quiver, те научили да израђују дигиталне квизове уз помоћ апликације Kahoot. 


\section{Очекивани ефекӣи ирроїрама}

Представљањем пројеката реализованих у Дечјем одељењу Библиотеке града Београда, разменом знања и идеја, те кроз практичан део примене алата и апликација богатог едукативног и креативног потенцијала полазници семинара били су инспирисани и охрабрени да на сличан и иновативан начин користе ИКТ алате при организовању и реализовању радионица за децу и младе у својим библиотекама. Стечена знања и вештине утицали су на формирање позитивног става библиотекара према информационим технологијама, а садржај програма подстакао их је да прате интересовања својих младих корисника, усавршавају се, упознају нове трендове, те иду у корак са временом како би понудили услуге адекватне потребама нових генерација.

\section{Метиодолоіија за йраћенье и вреgнованье ирроірама}

По завршетку семинара спроведено је завршно формативно вредновање. Полазницима је дат упитник у папирној или електронаској форми у којем су се анонимно могли изјаснити о квалитету реализованог семинара и могућности примене стечених знања. Семинар је оцењен просечном оценом 4,63. Оценом од 1 до 5 оцењене су следеће појединачне ставке:

- Садржај семинара - просечна оцена 4,8

- Начин излагања реализатора обуке - 4,8

- Похађање семинара ће унапредити рад - 4,5

- Мотивисаност да се савладају представљени алати и програми $-4,8$

- Услови за рад (просторни и технички) - 4,2

- Општа оцена реализатора семинара - 4,7.

На питање да ли би колегама препоручили семинар 98\% полазника одговорило је позитивно. Друге теме које су предложене да се уврсте у неки будући семинар биле су: фотошоп програм, унапређење сајтова библиотека, вики-алати, дигитализација. Одговори на питање шта се полазницима семинара највише допало били су разнолики: оживљавање прича помоћу гиф елемената, storytelling техника приповедања прича, разноврсност дигиталних алата, динамичност излагања, практичан рад, иновативност, вештина презентовања, могућност примене бесплатних алата у практичном раду са децом и младима, интерактиван приступ, поштовање наја- 
вљене сатнице семинара, смењивање активности и наизменично излагање предавача, Windows Movie Maker програм за едитовање филмова, Kahoot квиз, ентузијазам предавача, бројни примери из праксе, могућност постављања питања у току предавања, помоћ приликом практичног рада и испробавања дигиталних алата. На питање шта се полазницима најмање допало на семинару одговори су били готово једногласни - брзина, капацитет и застарелост рачунара, са изузетком одличних услова у Рачунарском центру ЦСУ Лесковац.

Упућени су и предлози да се направи наставак семинара „Алатке у руке 2", на којем би се полазници упознали са новим алатима, али и приказали како су применили знања стечена на претходном семинару.

Спроведено је и одложено вредновање ефеката реализације програма. Одређени број колега, након невеликог временског периода, као повратну информацију послао је оригиналне, духовите и иновативне радове који су настали током радионица за децу, а као резултат примене знања стечених на семинару. Тиме су потврдили очекиване ефекте програма и њихов допринос унапређењу квалитета рада у библиотечко-информационој делатности, а то су:

- примена ИКТ алата при организовању радионица за децу и младе при библиотекама,

- развијање иновативних идеја у раду са децом и младима,

- унапређење информатичке компетенције библиотекара,

- организовање приповедачких радионица уз примену компјутерских програма и дигиталних алата помоћу којих креирају и илуструју визуелно атрактивне и естетски обликоване приче,

- самостална израда мултимедијалних садржаја.

\section{Закључак}

Талас дигиталне револуције који је преплавио и унео промене у безмало све области живота и рада намеће низ изазова пред библиотекаре, а поготово пред оне чији је рад у најужем смислу везан за децу и младе, тј. за корисничку групу која је поникла у дигиталној ери и која не познаје живот пре интернета и мобилног телефона. Изазови као што су проналажење иновативних начина употребе информационих технологија у радионицама и програмима за децу и младе при библиотеци, подстицање читања и креативности код деце уз помоћ дигиталних технологија, подршка учењу и новим приступима претраживању и усвајању информација, развој ин- 
формационе писмености захтева пре свега унапређење информатичких компетенција самих библиотекара и стално стручно усавршавање.

Акредитовани семинар „Алатке у руке: креирање и анимација прича уз помоћ ИКТ мајстор(иј)а" саржински је конципиран управо у складу са новонасталим потребама библиотекара и жељом да се кроз бројне примере добре праксе, складно избалансиране са теоријом, пружи подршка у суочавању са изазовима које дигитална револуција доноси. Охрабрује ситуација коју су аутори и реализатори семинара на терену затекли, да највећи број библиотекара дигиталну револуцију не схвата као претњу већ као шансу за проналажење нових модела рада. Овакве напоре библиотекара да се крећу у брзом ритму које намећу нове технологије и да држе корак са корисницима који чине њихову циљну групу требало би подржати и кроз већу понуду формалних видова усавршавања. 


\section{Literatura:}

1. Anđelković, Nataša. Dete i računar u porodici i dečijem vrtiću. Beograd: Beoknjiga; Novi Sad: Centar za razvoj i primenu nauke, tehnologije i informatike, 2008.

2. IFLA Sekcija za decu i mlade. Smernice za bibliotečke usluge za decu. https://www. nb.rs/view_file.php?file_id=1831 (preuzeto 22. 3. 2019). (na ćirilici)

3. Kuzmanović, Dobrinka, Vesna Zlatarović, Nataša Anđelković, Jelena Žunić-Cicvarić. Deca u digitalnom dobu: vodič za bezbedno i konstruktivno korišćenje digitalne tehnologije i interneta. Beograd: Užički centar za prava deteta, 2019. https://www. unicef.org/serbia/media/10366/file/Deca_u_digitalnom_dobu.pdf (preuzeto 19. 5. 2019). (na ćirilici)

4. Narodna biblioteka Srbije. Stalno stručno usavršavanje zaposlenih. Odluka o akreditaciji programa stalnog stručnog usavršavanja u bibliotečko-informacionoj delatnosti. (preuzeto 25. 3. 2019). (na ćirilici)

5. Službeni glasnik RS br. 52 (2011). (na ćirilici)

6. Službeni glasnik RS br. 18 (2013). (na ćirilici)

7. Starčević, Nataša. „Efekti korišćenja medija u ranom uzrastu”. Digitalne medijske tehnologije i društveno-obrazovne promene 4. Novi Sad: Filozofski fakultet, Odsek za medijske studije, 2014. http://odsek.medijskestudije.org/wp-content/uploads/2011/03/Zbornik-Digitalne-tehnologije-FINAL.pdf\#page=301 (preuzeto 28 . 3. 2019).

8. UNICEF. Čitanje sa decom. https://www.unicef.org/serbia/sites/unicef.org.serbia/ files/2018-07/Citanje-sa-decom.pdf (preuzeto 25. 3. 2019).

9. Veličković, Sonja. „Edukacija vaspitača za primenu IKT u vrtiću”. Sinteza, Međunarodna naučna konferencija Univerziteta Singidunum (2014). http://portal.sinteza. singidunum.ac.rs/Media/files/2014/375-378.pdf (preuzeto 28. 3. 2019). 


\begin{abstract}
Jasna Brkić
brkicjasna011@gmail.com

Violeta Đorđević

violeta_djordjevic@yahoo.com

Belgrade City Library

\section{TOOLING UP: PROFESSIONAL DEVELOPMENT PROGRAMS OF LIBRARIANS FOR THE IMPLEMENTATION OF DIGITAL TOOLS IN THE WORK WITH CHILDREN AND YOUTH}

\begin{abstract}
The introductory part of the paper presents the advantages and positive effects of the implementation of digital technologies in the library when working with children and young people in order to develop reading habits and creativity from the earliest age. Due to the digital revolution, the library profession is faced with new challenges. It seemed necessary to systematically develop a positive attitude of librarians towards new technologies, empowerment of IT competencies, continuous education, and encouragement for the use of digital tools in their work with children and young adults. However, the analyses of accredited programs for continuing professional development in library and information profession, approved by the National Library of Serbia in the period from 2014 to 2017, show the lack of professional development programs aimed at encouraging children to read with the use of new technologies. The paper, further on, presents the Belgrade City Library's seminar implemented during 2018 - „Tools in hands: creation and animation of the stories with the help of ICT tools”. This accredited seminar summarizes the knowledge and rich experience in the field of implementation of new technologies when working with children and young adults in the libraries. Finally, the results of the evaluation of seminar conducted through an anonymous questionnaire filled in by its participants are presented and analyzed. The interest of a large number of librarians for the seminar dealing with new technologies shows a desire and readiness of librarians to master digital tools in order to use them in an innovative way. This indicates that more seminars concerning the work with children need to be organized, along with the incorporation of new technologies into the work of librarians at children's libraries.
\end{abstract}

Keywords: encouraging reading, digital tools, new technologies, reading habits, professional development for librarians, accredited seminar, children's libraries.

Примљено: 14. априла 2019.

Исправке: 13. маја 2019.

Прихвћено: 31. маја 2019. 